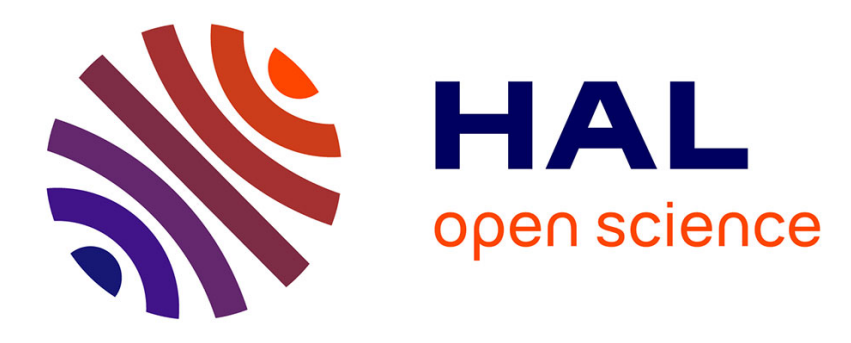

\title{
The Anti-Risorgimento as a transnational experience Simon Sarlin
}

\section{To cite this version:}

Simon Sarlin. The Anti-Risorgimento as a transnational experience. Modern Italy, 2014, 19 (01), pp.81-92. 10.1080/13532944.2013.871422 . hal-01698469

\section{HAL Id: hal-01698469 \\ https://hal.science/hal-01698469}

Submitted on 1 Feb 2018

HAL is a multi-disciplinary open access archive for the deposit and dissemination of scientific research documents, whether they are published or not. The documents may come from teaching and research institutions in France or abroad, or from public or private research centers.
L'archive ouverte pluridisciplinaire HAL, est destinée au dépôt et à la diffusion de documents scientifiques de niveau recherche, publiés ou non, émanant des établissements d'enseignement et de recherche français ou étrangers, des laboratoires publics ou privés. 


\title{
The Anti-Risorgimento as a Transnational Experience
}

\author{
Simon Sarlin
}

\section{Risorgimento and Anti-Risorgimento}

It must no longer be necessary to justify study of the oppositions to Italian unity as Arnaldo Salvestrini did in 1967, in the name of a general interest in the activity of Cavour and his immediate successors, with the idea of "examining more closely the resistances and reactions aroused by this activity to better evaluate all the complexity of the operation and meanwhile allow us to understand the means and forms adopted by the national movement while it was being realised - modes and forms closely linked to the international context" (Salvestrini 1967, 214). Since the appearance of this pioneering study of the anti-unity movement in Tuscany, the revival of studies of Italy in the $19^{\text {th }}$ century has largely destroyed the value of the long-standing, absolute and exclusive reference to the formation of national unity and its actors. Now the Antirisorgimento - understood here as the ensemble of conservative oppositions to Italian unification - is recognized among historians, as evidenced by the inclusion of a homonymous entry in the recent volume devoted to Italy of the Risorgimento (Davis 2008). But it remains true - and important to stress - that the anti-unity movement was a rather serious threat to the new regime that issued from the revolutions of 1859-1860 and conditioned in a significant way its domestic and international policy for a very long time.

To examine the forms and impact of the conservative opposition to unification is all the more justified because it is a key element in the controversies that currently agitate the historiographic and public debate on the formation of the Italian nation-state, particularly as regards the south of the peninsula. For the modern opponents of the country's political unity, the scope of the contestation that the new state faced in the 1860 s is a certain sign that the project of the unifying nationalists aroused the indifference of the masses at best. It is easy for the latter to recall that around 1863, the repression of the "great banditry" (grande brigantaggio) mobilised more than half the national army in the south of the peninsula, or that in 1869 , the re-establishment of an unpopular tax on milling provoked some revolts in central Italy that were clearly anti-unity in tone, which the army bloodily repressed (see for example Viglione 2001). Meanwhile, the repressive means deployed by the first unity governments are proof of the artificial and aggressive character of unification, even (from a southern 
standpoint) of its assimilation to an enterprise of conquest and then colonial exploitation. From this inherent vice derive, they say, many of the evils of Italy today, starting with the nagging "southern question". The force acquired by this critical discourse may be measured by the response that the President of the Republic, Giorgio Napolitano, felt he should offer in his speech to Parliament at the opening of the celebrations of the $150^{\text {th }}$ anniversary of Unity (Napolitano 2011).

In its intentions - and consequently in its conclusions - this interpretation arises much more from a passionate indictment, fed by the rise in autonomist demands since the 1990s, than from an historical evaluation (its rhetorical and argumentative continuity with the antiunity polemics of the 1860 s is striking in this respect). But it is possible, without falling into such travers, to recall that the explosion of "banditry" in the continental Mezzogiorno in 1861 exercised a decisive influence on the debates on political and administrative organisation that led to abandoning the autonomist project for the sake of French-style centralisation in which the prefects exercised a heavy control over the provinces, which was unpopular from the start. Or that, to deal with the peril of "reactionary" subversion (as much as with the republican opposition), the unity governments had to resort to repressive measures that were in clear contradiction with the liberal principles affirmed by the new regime - suppression of "bad newspapers", arrests and preventive detention, proclamation of a state of siege, summary execution of "rebels" seized with weapons in hand - and the international publicity could only weaken the legitimacy of a state whose leaders had, following on from Cavour, justified its formation in the name of the idea that only union under a liberal moderate monarchy would be able to resolve the problem of political instability specific to Restoration regimes. The Anti-Risorgimento thus contributed to aggravating the close dependence of the young unified nation on the conditions of international life, just as much as it benefited from the internationalisation of the "Italian question" in the course of the previous two or three decades.

At the same time, the anti-unity struggle permitted the crystallisation in the $1860 \mathrm{~s}$ of a counter-revolutionary current at the level of the unified peninsula. Certainly, the ideological bases of the Anti-Risorgimento were in place well before the project of national unification took shape in the middle of the 1850s. These bases were anti-liberalism and anti-modernism, inspired by critiques of the Enlightenment and the French Revolution, which had guided the reactionary policies implemented by the directors of the Restoration since 1815 , and which structured the counterrevolutionary myth of an international plot hatched by the "Sect", which had already furnished the key for interpreting the revolutionary movements of 1848-1849 
(Del Corno, 2002). Yet before 1860 we cannot speak of a coherent doctrinal system, but rather of "spontaneous and personal positions" proper to a "group that found a certain unity of objectives only as a function of some doctrinal fundamentals and especially some common pragmatics" (Leoni, 1975, 14). Before this date it is impossible to find the trace of a serious attempt at coordination among the Italian apostles of ultra-conservatism. The victorious rise of the nationalist movement gave the disparate forces a common adversary, as well as goals that could be shared by the papacy, the legitimate princes, and their respective defenders (not without ambiguity, as we shall see).

But this dual process of asserting the Anti-Risorgimento not only closely depended for its success (or rather its failure) on international factors, which must be understood in a transnational perspective. Just like the movement of which it was the inverse, the antirisorgimentist struggle was conducted outside Italy and in many countries. It was incarnated in forms of mobilisation we may characterise as transnational (using the definition given by Saunier, 2009) because they were dissociated from official institutions (such as the armed volunteers that transcended frontiers and national belongings) and because they relied on international networks of mutual aid and militancy closely tied to the counterrevolutionary camp. Particularly important from this perspective was the flow of several thousand volunteers into Rome between 1860 and 1870 to take up arms against the revolution for unity.

\section{Exporting the Anti-Risorgimento: limits of internationalisation}

The internationalisation of the anti-unity struggle was partly a response to a constraint that was imposed on the leaders of the old states. In 1859, the weakening of the Austrian Empire could be seen as the direct cause of the successful revolutions that led to the fall of the small sovereigns of central Italy and would force them to take the route of exile: Grand-Duke Ferdinando IV of Tuscany to Dresden, then to Lindau in Bavaria; Duchess Marie-Louise of Parma to Warteg in Switzerland; Duke Francesco V of Modena to Austria (followed by a portion of his army that under the name of "brigata estense" maintained its military organisation until September 1863 and whose numbers oscillated between 3,000 and 5,000 men). After the fall of Gaeta in February 1861, which culminated the enterprise of conquest initiated by Garibaldi and his Mille, the King of Naples Francesco II found refuge in Rome, under the protection of Pius IX, until 1870. All these deposed sovereigns were surrounded in their exiles by courts frequented by a large legitimist emigration that was fleeing the revolution or departing out of fear of persecution. All would maintain in their service 
diplomatic agents charged with defending their rights among the conservative powers; the most important of these diplomatic networks was by far that in the service of the Bourbons of Naples, which answered to instructions from a veritable government in exile that was only dissolved after the Austrian defeat of 1866 (Leoni, 1979; Leoni, 1984).

Since 1815 , the pontifical governments had wagered on the insertion of the papacy into the international concert as the best way of guaranteeing its temporal power in the face of with an increasingly inextricable domestic situation. The events of 1859-60, which resulted in the amputation of two-thirds of the pontifical territory without provoking a concrete reaction from the Catholic powers, demonstrated the limits of this strategy in an international context of upheaval even compared to 1848-49. Faced with the threat of new external aggressions and internal contestation, the response of the papacy, however, continued to take place essentially on the terrain of diplomacy and foremost around the maintenance in Rome and in the Latium of French troupes that the regime of Napoléon III had kept there since 1849 with the mission of ensuring integrity and domestic order. To support this diplomatic activity, the pontifical leaders did not hesitate to encourage, through national Churches, agitation by public opinion to spontaneously and massively demonstrate in many countries, especially France, in defence of the temporal power of the papacy. Moreover, the loss of territories that were the most developed economically had heavy consequences for the financing of the Church's government structures; this forced the papacy to appeal to the generosity of the masses of the faithful, first in the form of international loans, then through the international organisation of the collection of the Peter's Pence (Pollard 2005, 21-54). In parallel, the reconstitution of the pontifical army, previously voluntarily maintained in the narrow confines of an instrument for keeping public order and for political repression, after 1860 relied on a policy of active enrolment whose reservoirs were necessarily found abroad.

But the internationalisation of the anti-unity combat also represented a strategic calculation. Many conservative Italian leaders saw the intervention of foreign armies as the sole effective bulwark against domestic contestations, which sometimes brought them toward a policy of the worst. One example is the plan for Pius IX to flee in September 1860, supported by Xavier de Mérode notably, which was supposed to precipitate a reaction by European Catholic powers. After unification, the hope of a restoration rested principally on the expectation of foreign intervention in the peninsula, by virtue of a belief firmly anchored in conservative circles that the revolutionary movement would sooner or later alienate the great powers (as it had in 820-1821, 1830-1831 and 1848-1849). It was this conviction that made Ferdinando IV of Tuscany, in the autumn of 1860, that he "was not losing courage, and 
still less the hope of a not-too-distant reestablishment of order" because "although the situation [was] very confused... the current tendency could not persist and [ought] to halt due to its very nature" (quoted by Salvestrini 1967, 145-6)). Even the most ardent partisans of a popular counter-revolution, enthusiastic about the development of a popular guerrilla uprising in the continental Mezzogiorno and the hope of a new "Santa Fede" could not ignore the fact that a victory by armed force was illusory without external support, and that their capacity to maintain the flame inside their partisans in Italy was very dependent on the support proclaimed by the major conservative powers.

However, on the ground the reactionary leaders did not take long to experience the painful fact that - in the phrase of a British ambassador during the Second World War "governments-in-exile are cards, not players" (quoted by Shain, 1989). The attitude of conservative states to the cause of Don Carlos during the Spanish civil war between 1833 and 1840 - which shied away from a military engagement at the same time as the liberal powers were supporting the constitutional party of Infante Isabella - had already furnished a clear illustration. In the $1860 \mathrm{~s}$, the reticence of conservative leaders to translate their flaunted opposition to Italian unity into effective help (financial and material) to its opponents was certainly the principal limit to the scope of the anti-unity fight. In this sense, the cautious attitude of Rechberg and his successors at the head of the Austrian chancellery reflects just as much the real internal difficulties of the Habsburg Empire as "the rather contradictory mood of despair, of complacent passivity, and of self-imposed paralysis that characterised the conservative camp generally in this period" (Elrod, 1984, 436).

In an era marked by the triumph of Realpolitik, those responsible for the foreign policies of conservative powers, torn between the pro-legitimist pressures of their sovereign and various currents in parliament or public opinion that were favourable to a normalisation of relations with the new Italy (to which the constitutional reforms at the end of the 1850 in Prussia and Austria would give new weight), tried above all to temporise. Some were content to employ double talk. The assurance conveyed by diplomacy that the conservative European leaders were in fact searching for a reason not to intervene in Italy explains in large part why it was decided in Turin to give a carte blanche to the military authorities in the South, in the conviction that a rapid crushing of the revolt would represent a better result than the damaging publicity that repression might cause in domestic and especially foreign opinion. In fact, the calls to safeguard the principle of legitimacy and the solidarity of the conservative world launched by the papacy and the former Italian princes did not have much weight compared to 
the desire to recognize what had already taken place in Italy (by Russia and Prussia as of 1862, by Spain and Bavaria in 1865, and by Austria in 1866).

\section{Armed volunteers and the "white internationale" in the anti-unity combat}

However, the existence of vast Catholic and conservative sectors that were spontaneously hostile to the nationalist revolution in Italy offered reservoirs of energy that the agents of the Anti-Risorgimento did not fail to exploit. The papacy was obviously best placed to nourish this mobilisation due to the universal stakes of the Roman question and the support of the international structures of the Catholic Church. In his encyclical of 19 January 1860, Pius IX exhorted his clergy to "enflame each day evermore the faithful confided to [their] care, so that under [their] steering, they would not cease to employ all their efforts, zeal and thought for the defence of the Catholic Church and the Holy See, and the maintenance of the civil power of this same See [...] that all Catholics have an interest in protecting." Thousands of volunteers responded to the pope's call to strengthen the small pontifical army now threatened by developments of the unity movement under the command of General Lamoricière, which was crushed by the troops of King Victor-Emmanuel in the Marches in September 1860. The celebration of the "martyrs" to the pontifical cause was at the centre of a vast campaign, through funeral ceremonies and episcopal mandates, designed to remobilise Catholic opinion against the new developments in the unity process. Between 1861 and 1870, more than 7,000 men from almost twenty countries (but principally from France, Belgium and Holland) enlisted for variable periods in the ranks of the pontifical zouaves (Boutry 2002).

The engagement of these thousands of volunteers presupposed a vast mobilisation of the Catholic world, notably on the financial level. In parallel to the constitution of a network of committees charged with collecting Peter's Pence by which the faithful were called upon to fill the papacy's treasury, there arose - usually on the initiative of the same circles associations that adopted the mission of organising and (especially) financing, by means of gifts and subscriptions, the enlistment and arming of recruits for the Roman army. In 1867, in the wake of the fighting in Mentana that provoked Catholic emotion, a zealous defender of the the papal cause (Baron Onffroy) exhorted the "pious parishes" of his diocese of Nantes to contribute to pay "as much as possible" for the expenses of travel to Rome by new volunteers, while it was incumbent on the richer families to pay for the upkeep in situ of some of these recruits. By the end of the year, the local subscriptions as published by the Semaine religieuse in the diocese enabled maintaining 150 zouaves (Faugeras 1984, 397). It was also 
the victory of the pontifical troops over the Garibaldians that led to the creation in Montreal, in December 1867, of a committee in charge of recruiting a battalion of Canadian zouaves that set off for Rome a few weeks later (a similar initiative launched in the United States by The Freeman's Journal had no such success) (see Marraro, 1944)). A certain spirit of competition among Catholic nations was part of the success of this mobilisation: the president of Paris' St. Peter's Committee (Émile Keller) noted that the outburst aroused by the 1867 campaign had raised the zouaves to 5,000 men, but that now France should give in 1869 at least 1,500 new volunteers "to keep the rank it occup[ied] in this great manifestation of Catholic devotion..." (quoted by Faugeras 1984, 398).

At the same time, the resistance of the King of Naples and the revolt by southern peasants against the unity state aroused ferment within the small world of European legitimists. During the siege of Gaeta, Neapolitan diplomats in Paris, Berlin, Vienna and Madrid declared they were assailed by the demands of individuals wanting to put themselves at the service of Francesco II. Despite the discouraging response from the Bourbon authorities, which were trying at the time to reduce the overstaffing of the stronghold's garrison, forty-some volunteers from France (more than half of them), Belgium, Switzerland, Germany, Austria and Spain embarked spontaneously to Gaeta. In the spring of 1861, when the popular revolt exploded, the King of Naples and his partisans in exile were trying to channel this outburst of sympathy into the service of their plans to reconquering the kingdom. An international clandestine organisation was set up, whose kernel was composed of Bourbon diplomatic agents, ex-officers of the royal army, émigrés from the south, and local sympathisers, with the mission of collecting funds, recruiting combatants, and preparing a grand expedition to Calabria. In the end, this was reduced to the disembarkation of twentysome volunteers led by the Carlist General José Borges, whose venture concluded tragically after a few weeks. Between the spring of 1861 and the summer of 1862, this mobilisation nevertheless resulted in sending a hundred foreign volunteers - between 100 and 200, it is hard to know - to join the bands conducting guerrilla war in the Abruzzi, where Francesco II had named another Carlist general (Rafael Tristany) as head of his "troops" (Sarlin 2012).

By accepting or soliciting foreign volunteers, the leaders of the anti-unity combat could not hope to win the power struggle with their adversary, as witnessed by the very modest military role assigned to the pontifical zouaves after 1861 (to maintain order in what remained of the pontifical state, and after 1867 the repression of brigandage in the Southern Latium). The presence of these thousands of foreign volunteers in Rome served above all to incarnate the strength of European resistance to the challenge to the temporal power of the 
papacy by inserting itself into the unprecedented effort to mobilise the Catholic world, guided by the ideal of a "ninth crusade". The Neapolitan leaders in exile were persuaded that the presence of a corps of foreign volunteers was a necessary condition for disciplining the guerrilla troops and leading them toward military objectives. But the engagement of foreigners in the service of the Bourbons of Naples primarily had symbolic value by demonstrating the strength of the international support for the legitimist cause and by giving credit to the political and ideological character of the guerrilla force that was contesting the Italian government and its partisans in Europe.

The involvement of foreign volunteers in the Anti-Risorgimento struggle was not the first experience of bellicose solidarity in the counterrevolutionary camp. The army of Dom Miguel in Portugal in 1833-34, then that of Don Carlos between 1834 and 1840, had also welcomed voluntary fighters from all over Europe to defend the cause of an absolutism that for them was incarnated by these two princes and to combat the liberalism then conquering the Iberian peninsula. In the light of these various manifestations of the internationalisation of the counterrevolutionary struggle, it does not seem illegitimate to speak, as do historians like Jean-Clément Martin and Jordi Canal, of a "white internationale" in the $19^{\text {th }}$ century, that fought for throne and altar (Martin 200; Canal 2011). To speak of an "internationale" might seem improper regarding a movement that relied on no well-defined organisation, unlike the working class Internationale, nor even on a formal alliance of monarchs or their parties (like the attempt in the 1930s to regroup royalists, conservatives and nationalists throughout Europe, or else the union of Christian-Democratic parties, also nicknamed the "white internationale"). Instead, we are drawing attention to a transnational community of opinions, interests, values, and memories apt to arouse periodic international mobilisations for conflicts that were just as much civil wars as episodes in a vast political and ideological struggle.

During the first half of the $19^{\text {th }}$ century, military volunteers became a model of political engagement that was new and attractive, endowed with a strong emotive and symbolic charge. No doubt the success of this model owes much to the new conceptions of citizenship and heroism forged by the French Revolution and applied after 1815 to nationalist struggles (Mosse 1991). But the attraction of the volunteer force was not exclusive to the revolutionary, liberal, democratic or nationalist camps. The obvious influence of Romanticism in the representation of volunteers in arms resonated perfectly with the reactionary mentality and lent itself to the recuperation of traditional values and conceptions: the ideal of chivalric heroism, the spirit of a crusade, the fidelity to political and religious traditions, the sense of personal sacrifice. This shift was all the easier because the 
revolutionary rhetoric was itself saturated with borrowings from religion, as when it invoked the "holy cause" of freedom and the nation, encouraging the gift of self and created a veritable cult of its glorious dead as "martyrs". The Catholic Church, in the context of its fight against the Revolution, relaunched the martyrological cult through which the faithful were called upon to resist the new "barbarians" and to expiate the sins of an impious society. It insisted on the plebeian character of the first Christian martyrs, just like some of the volunteers who had fallen on the battlefields in 1860 , in order to demonstrate the universal scope of its combat (Viaene 2004). Against the background of an exacerbated political rivalry, the nationalist and Catholic-conservative movements each adopted a cohort of martyrs who "formed the basis for two rival cults that jostled against each other, at once bitterly hostile and intimately related" (Riall 2010, 256).

No doubt the volunteers in the service of the papacy or the King of Naples conceived of their engagement as a manifestation of solidarity with a cause they assimilated as a just combat against triumphant liberalism and in favour of political and religious traditions. For the European militants of the counter-revolution, the shaking of the Italian states under the blows of the liberal and unification movement was merely an avatar of the vast process shaking up traditional society, like what they were fighting in their own countries. A community of peril against a common adversary founded the need for counterrevolutionary solidarity:

"You know how many sacrifices we have made up to now," [the Carlist Francesc Tristany wrote in February 1861 in a letter to his brother] "and we aspire only to continue them as far as giving our lives, if needed, to defend the cause of our King. The sword we brandished in Spain will be drawn again to fight in favour of legitimacy wherever that is necessary. The revolutionaries are everywhere the same, and their plans always iniquitous." [Archivio di Stato di Napoli, Archivio Borbone, 1135, f 300 : letter from Francesc Tristany to one of his brothers in Paris (no doubt Rafael), Besançon, 21 February 1861]

What was happening in Italy resonated with past combats, founding the geographic and chronological continuity of the counter-revolution. The defence of the Papal States could take its place in the many echoes of the wars in the Vendée, because many of the volunteers came from western France and the Vendée insurrection was read retrospectively as resistance to a secular stranglehold (Martin 1989, 129). Inversely, the "brigandage" and its repression were almost systematically assimilated to the counterrevolutionary Vendée and to the Spanish insurrection against Napoléon. 
Recognizing the influence of ideological motivations in the volunteer army does not imply an exclusively political reading of it. Self-interest, opportunism, and the thirst for adventure also played a part. The example of the Carlist exiles that formed the major part of the volunteers in the service of the King of Naples well illustrates the difficulty of drawing a clear boundary between these different dimensions. At the start of the 1860s, Carlism traversed one of the crises that periodically affected it after military or dynastic events (e.g., the failure of the war of 1855-57, the fiasco of an attempt at pronunciamento in Catalonia in April 1860 and the death of the pretender a few months later). The confusion that reigned at the head of the party and the defection of some of its base to the conservative wing of the moderate party signified for the veterans the remoteness of any prospect of action in the short or medium term. In these conditions, to get involved with another legitimate sovereign might then appear, especially in the eyes of émigrés, to be the sole means of justifying the pursuit of intransigent combat in favour of the counter-revolution and to be able to resist the temptation of amnesty offered by the government of Isabel II. The great number of Carlists among the volunteers in southern Italy largely reflected the poverty into which exile had forced the former soldiers of Don Carlos. But of all the foreign volunteers in the service of the Bourbons of Naples, the Spaniards were those whose political motivations were the least disputable.

\section{The papacy and the Anti-Risorgimento}

Political and religious dimensions were closely intertwined within the AntiRisorgimento. Among those who took up arms in favour of the papacy were many who saw Italian unification as an overthrow of the political and social order as much as it was a pernicious enterprise of secularisation. Going to Rome was for Henri de Cathelineau going "to crush the revolutionary hydra and to save society" (Cathelineau 1909, 131).

Consequently, working for the restoration of ancient secular states was for most of the defenders of the papacy the best way of guaranteeing it from internal and external threats posed by the development of liberalism. It was this conviction that, after Castelfidardo and the dispersal of pontifical troops, pushed a number of volunteers to pursue the fight by passing into the Neapolitan army in the name of the idea that the King of Naples's cause was "so intimately tied to that of the Church that to support one [was] to support the other," as the Count of Sayve asserted in November 1860 in a letter sent from Gaeta to La Gazette de France. 
This imbrication between religious defence and political intransigence was reflected in the discourse of the pontifical leaders. Pius IX, as Giacomo Martina discovered from the pontiff's private correspondence edited by Pietro Pirri, was quite disposed to establish direct links between the defence of pontifical temporal power, the cause of the deposed Italian princes, and that of legitimism more generally (Martina 1986, 111-2). Thus during discussions about holding a hypothetical European congress on the Italian affairs in December 1859 , the pope sent a letter to the Catholic sovereigns to exhort them to defend the temporal domain of the papacy in the name of the indispensable independence of the pontiff, but also the obligation to struggle against "a new principle, eminently subversive, that peoples may at will get rid of their legitimate sovereign, as happened in Italy" - which would be officially condemned by the Syllabus of 1864. But as Giacomo Martina also stressed, the expression of this solidarity between fighting for the papacy and for other Italian princes had clearly evolved over time: very present and asserted in the years of unification between 1859 and 1861 , this aspect tended later to fade, as the papacy's hesitation to put on the same plane the cause of the Holy See (rights that were supposed to be imprescriptible) and that of the dispossessed princes (of a historical and thus contingent nature) became more and more manifest.

One clear expression of this ambiguity was furnished in 1862 by the response of Pius IX to a plan for a common programme with the forces of the Anti-Risorgimento. Expressing himself in the name of all the dispossessed princes (in reality, the King of Naples had refused to be associated with this initiative), the Grand-Duke of Tuscany had exhorted the pope in a letter "solemnly to recall all the Italian peoples to religion and concord" by announcing that he was placing himself at the head of an Italian confederation "through which it would be possible to reconcile the exigencies of the past and of the future, the ancient and future glories, history that is accomplished and history on the march, the rights of princes and those of peoples, the needs and interests of each state with the needs and interests of the common Fatherland" (Pirri 1951, 2:240-42). This program was merely a reprise of the "neoGuelph" tropes in vogue in the 1840s, which had nourished the dream of a compromise between leadership circles and the most moderate sectors of the liberal-nationalist current without every arousing series attention from the former - now being recuperated and actualised in the light of circumstances produced by the unexpected victory of the unity movement. However, just as in 1847 Pius IX did not consent to engage the papacy in a collective approach that was politically constraining. In his answer, the pontiff observed that 
he had never lost an opportunity to defend the rights of the Italian sovereigns, but that he did not think "the moment had come to address words to the Italians" in the sense they wanted, "for these words would certainly animate the hearts but not the arms of oppressed peoples"; one should not hide the fact that the desired goal could not be attained "without the auxiliary of regular troops" - understood as meaning as long as Austria maintained the wait-and-see attitude it had adopted in 1860 - but it was not up to the pope to encourage a path that contradicted "the sanctity of his character", which would not fail to bring down on him the "attacks of a press that was excessively brazen and impudent". Better then, Pius concluded, to "leave it to time open up the path onto which [the Italian princes] should direct their feet" (Pirri 1951, 2:246-47).

This refusal expressed motivations deeper than the absence of circumstances favourable to the realisation of the project advanced by the deposed princes. The combat for the defence of the papacy had served as a powerful catalyst in the process of shaping international Catholic opinion that had been gestating since the 1830s. It had relied in the first place on the rise of religious congregations and popular devotions, which historians of Catholicism often describe as a veritable "revival" after the depression of the revolutionary period. This movement of expansion had served as fertile soil for the emergence of forces organised around the goals of propagating and defending the interests of the Church, under the direction of leaders - ecclesiastical and increasingly the laity-ready to resort to a whole panoply of modern means of political action and communication addressed to the masses such as newspapers, petitions, meetings and subscriptions (Viaene 2002; Viaene 2012; Clark 2003). The events of 1848-1849, which mobilised the Catholic world in favour of a pope threatened by the liberal revolution, might appear as the "dress-rehearsal for the more comprehensive and persistent mobilisation ten years later" (Viaene 2002, 139). The international campaigns by which Catholics acted in defence of the papacy in 1849 and especially after 1859 considerably strengthened their feeling of forming an international community forged by concrete objectives and structured by new permanent organisations (like the Peter's Pence, inaugurated in 1848 on a temporary basis and revived in the 1860s). In parallel, these campaigns consolidated the place of the papacy within the Catholic movement. Over the course of the preceding decades, Rome had played a central role in the diffusion of popular devotions and the clerical and laity networks that promoted them, which had in return strengthened the ultramontane orientation of a majority of the clergy and the faithful, following a "dialectical interlocking of curial authority and popular aspirations" (Clark 2003, 19). This "Romanisation" of Catholicism, finally, was reinforced, thanks to the 
industrial production of images of Pius IX and to the development of the pilgrimage to Rome, by a growing identification of the Catholic Church with the figure of its pontiff, who became for the first time the object of veritable popular veneration (Horaist 1995).

The organisation of a Catholic international was by no means incompatible with the defence of legitimism, whose representatives were as visible within religious associations as they were present around the Curia. In 1865, the welcome Rome gave to the Italian deputy Vegezzi, who had come at the pope's invitation to try to find a solution to the problem of vacant dioceses in Italy, had the effect of a thunderclap because it was interpreted by many as the sign of a coming swerve in the pontifical policy toward the neighbouring kingdom. In reality, at no time did the pontifical leaders had the intention of compromising on the political question; on the contrary they were relying on a public opinion campaign by intransigent Catholics, relayed by the Austrian government and the deposed princes, to restrict the negotiations to the narrowest possible limits and thus avoid the papacy's having to advance on the political terrain against its will. The papacy would remain firm in its positions, even after the recognition of the kingdom of Italy by Austria in 1866, which induced the dukes to renounce their rights in order to obtain the restitution of their personal fortunes and then led to the dissolution of the Neapolitan government in exile. It was only in 1882, four years after the death of Pius IX that the ecclesiastical annual gave up grouping the Italian dioceses according to the old political borders of 1859.

But the evolution of the power struggle between the Catholic movement and the Legitimist movement rapidly played in favour of their regrouping under the Church's banner. Over the years, the demobilisation of militant legitimism in the old states hastened the formation of a vaster assembled Catholic-Conservative movement with a view to the general elections of 1865, behind the slogans of defending the Church's interests and the moral order. In the South of the peninsula, the enormous resources injected by the Italian state in the repression of "brigandage" ended in the slow but ineluctable stifling of the anti-unity guerrilla force, whose ranks had been abandoned by the last foreign volunteers at the approach of the winter of 1864. The Austrian defeat of 1866, by leaving the papacy to itself (after the French troops had evacuated Rome a few months previously, before coming back in another form after Mentana), appeared to give the signal for a new stage in the integration of various Catholic and conservative movements. When representatives of the Catholic world flocked to Rome to prepare the future council between 1868 and 1870, there flourished in the shadow of the Vatican meetings between actors in the Catholic militancy and plans for international coordination, which would lead after the taking of Rome to the foundation of $L a$ 
Correspondance de Genève, a body whose mission was to provide the Catholic press with a central source of information thanks to a network of laity activists organised by a permanent office (Viaene 2002, 157-8; Lamberts 2002).

Some historians have seen this initiative as the incarnation of the "black internationale" denounced by Bismarck. But it should be stressed that the Geneva association continued to associate laity circles that were largely legitimist with the enterprise of forming and directing militant and transnational Catholic opinion, with the blessing of the papacy and in the narrow limits imposed by the latter. What springs out of the brief experiment - from 1870 to 1878 - is the Curia's circumspection faced with a semi-autonomous organisation of the laity, which did enable it to conduct a parallel diplomacy. But it was always suspected of subordinating the defence of the Church to its own "political" agenda (a tension that will be found permanently in the relations of the papacy with partisan formations of Catholic clerical inspiration). In return, Rome's refusal to grant an official mandate and leadership to the whole Catholic movement aroused the frustration of agents who demanded to act openly at the head of a new crusade to restore the "social reign of Jesus Christ" - with the same weapons and in direct rivalry with the Workers' Internationale. The result was to provoke their disengagement.

Tackling the transnational dimension of the Anti-Risorgimento makes us pay attention to a phenomenon that is still poorly understood: the regular manifestation of an ideal of international solidarity in the $19^{\text {th }}$ century counter-revolution, prolonged in the experience of exile, sorts of "white" and "black" internationales, sisters and antagonists of the liberal or democratic internationales that they confronted on the same terrains during conflicts that were both civil wars and episodes in a vast international ideological struggle. A struggle against liberalism and revolution and one in defence of legitimacy and of Catholicism, were the principal ingredients of this transnational community, periodically reinvigorated by the experience of war, which united European counterrevolutionaries and sharpened their identity. Although regularly beaten on the battlefield, this transnational dimension played an important role in the survival of various counterrevolutionary movements and of a European identity for the Counter-Revolution that lasted at least until the end of the century. It also allows us to acknowledge the influence of a Romantic conception of political engagement through the mobility of small groups and categories of a fraternity that was common to all political families in this era. In this sense, it is undoubtedly more accurate to speak of an 
internationalism inherent in the European political culture of the $19^{\text {th }}$ century, of which the counter-revolution was firmly a part.

\section{REFERENCES}

Boutry, Philippe, “Zouaves, pontifical” in The Papacy: An Encyclopedia, edited by Philippe Levillain, 3:1642-46. New York: Routledge, 2002.

Canal, Jordi. "Internationale blanche" in Dictionnaire de la Contre-Révolution: XVIIIe-XXe siècle, edited by Jean-Clément Martin, 307-311. Paris: Perrin, 2011.

Cathelineau, Victoire. Le Général Comte de Cathelineau: Chevalier de la Légion d'honneur, commandeur de l'ordre de Pie IX, chevalier de la Tour et de l'Épée et de Don Miguel de Portugal: sa vie et ses mémoires. Rome-Paris-Brussels: Desclée De Brouwer, 1909.

Clark, Christopher, "The New Catholicism and the European Culture Wars" in Culture Wars: Secular-Catholic Conflict in Nineteenth-Century Europe, edited by Christopher Clark and Wolfram Kaiser, 11-46. Cambridge: Cambridge University Press, 2003.

Davis, John Anthony. "L'Antirisorgimento” in Gli italiani in guerra: conflitti, identità, memorie dal Risorgimento ai nostri giorni. 1. Fare l'Italia: unità e disunità nel Risorgimento, ed. Mario Isnenghi and Eva Cecchinato, 753-769. Turin: UTET, 2008.

Del Corno, Nicola. “La setta e i complotti: un'ossessione reazionaria nell'Italia del Risorgimento". Belfagor 57 (2) (March 31 2002): 157-176.

Elrod, Richard B. "Bernhard von Rechberg and the Metternichian Tradition: The Dilemma of Conservative Statecraft” Journal of Modern History 56 (1984): 430-455.

Faugeras, Marius. “Un aspect local de la question romain: l'aide nantaise au Saint-Siège (1860-1870)". Annales de Bretagne et des pays de l'Ouest 91.4 (1984): 393-421. doi:10.3406/abpo.1984.3173.

Horaist, Bruno. La Dévotion au pape et les catholiques français sous le pontificat de Pie IX: 1846-1878: d'après les archives de la Bibliothèque apostolique vaticane. Rome: École française de Rome 1995.

Lamberts, Emiel. “L'Internationale noire. Une organisation secrète au service du Saint-Siège” in The Black International, 1870-1878: The Holy See and Militant Catholicism in Europe, ed. Emiel Lamberts, 15-102 (2002). Brussels: Institut historique belge de Rome. 
Leoni, Francesco. Storia della controrivoluzione in Italia: 1789-1859. Naples: Guida, 1975.

-Le carte delle rappresentanze a Vienna degli ex-ducati italiani: 1859-1866. Palerme: Thulè., 1979.

_.Il Governo borbonico in esilio: 1861-1866. Napoli: Guida, 1984.

Marraro, Howard Rosario. " Canadian and American Zouaves in the Papal Army, 18681870”, CCHA Report 12 (1944): 83-102.

Martin, Jean-Clément. La Vendée de la mémoire: 1800-1980. Paris: Seuil 1989. , editor. La contre-révolution en Europe, XVIIIe-XIXe siècles: Réalités politiques et sociales, résonances culturelles et idéologiques. Rennes: Presses universitaires de Rennes, 200.

Martina, Giacomo. Pio IX. 2, 1851-1866. Rome: Ed. Pont. Univ. Gregoriana, 1986.

Mosse, George. Fallen Soldiers: Reshaping the Memory of the World Wars. 1 vol. New York, 1991.

Napolitano, Giorgio. "Statement of Italian President Giorgio Napolitano at the joint Session of Parliament on the opening of celebrations of the 150th anniversary of Italian Unity" 2011. http://www.quirinale.it/elementi/Continua.aspx?tipo=Discorso\&key=2166.

Pirri, Pietro. Pio IX e Vittorio Emanuele II dal loro carteggio privato. II, la questione romana 1856-1864. Vol. 2. Rome: Pontificia Università Gregoriana, 1951.

Pollard, John Francis. Money and the Rise of the Modern Papacy: Financing the Vatican, 1850-1950. 1 vol. Cambridge: Cambridge University Press, 2005.

Riall, Lucy. "Martyr Cults in Nineteenth-Century Italy," Journal of Modern History 82.2 (2010): 255-287.

Salvestrini, Arnaldo. Il Movimento antiunitario in Toscana: 1859-1866. 1 vol. Florence: L. S. Olschki, 1967

Sarlin, Simon. Le Légitimisme en armes. Histoire d'une mobilisation internationale contre l’Unité italienne. B.E.F.A.R. Rome: Ecole francaise de Rome, 2012.

Saunier, Pierre-Yves. "Transnational," in The Palgrave Dictionary of Transnational History, ed. Akira Irie and Pierre-Yves Saunier, 1047-1054. Basingstoke: Palgrave Macmillan, 2009.

Shain, Yossi. The Frontier of Loyalty: Political Exiles in the Age of the Nation-State. Middletown: Wesleyan University Press, 1989.

Viaene, Vincent. “The Roman Question. Catholic Mobilisation and Papal Diplomacy during the Pontificate of Pius IX (1846-1878)," in The Black International, 1870-1878: the 
Holy See and Militant Catholicism in Europe, ed. Emiel Lamberts, 135-178. Brussels: Institut historique belge de Rome, 2002.

“"Gladiators of Expiation: The Cult of the Martyrs in the Catholic Revival of the Nineteenth Century," in Retribution, Repentance, and Reconciliation, ed. Kate Cooper and Jeremy Gregory, 301-316. Woodbridge: Boydell, 2004.

- "Nineteenth-Century Catholic Internationalism and Its Predecessor," in Religious Internationals in the Modern World: Globalization and Faith Communities Since 1750, ed. Abigail Green and Vincent Viaene, 82-110. Basingstoke: Palgrave Macmillan, 2012.

Viglione, Massimo, editor. La rivoluzione italiana: storia critica del Risorgimento. Rome: Il Minotauro, 2001.

- translated by Susan Emanuel 